\title{
An Ethnographic Approach to the Study of Folklore of Barumal Village in India
}

Avinash Gupta ${ }^{1}$, Sneha Roy ${ }^{2}$

\begin{abstract}
The focus of this ethnographic expedition is to study the folklore and traditions amongst the existing tribal populations of Barumal village in southern Gujarat, India. The fieldwork revolves around cultural and socio-economic aspects of their livelihood and this paper encompasses the knowledge from one such lens out of many. It tries to identify the importance of mythology and its roots. The data collected from three different population groups are Varlis, Kukanas, Dhodiya Patels that are set within the caste system based hierarchy inhabiting in the same region. The interview method was employed throughout with open-ended questions. The varied customs and traditions appearing in their lifestyle, occupation, and festivals are always associated with one god or another. The key informants felt the need to distinguish the history of their own tribe from the others by taking the help of myths passed down from their ancestors. Most of the key informants were mature adults including both males and females.
\end{abstract}

Keywords: folklore, ethnographic study, Indian tribes, myths, social anthropology, Gujarat

\section{Corresponding author contact details}

${ }^{1}$ Department of Historical Anthropology and Human Ecology. University of Goettingen, Germany.avinash.gupta@stud.uni-goettingen.de.

${ }^{2}$ Faculty of Humanities and Performing Arts. University of Wales, Trinity Saint David. United Kingdom. sneha.roy2207@gmail.com.

\section{Introduction}

The aim of this paper was to serve as a part of the dissertation submitted for the fulfilment of Bachelor's degree at Department of Anthropology, University of Delhi. It helped primarily in the learning process of conducting fieldwork for budding anthropologists. Our fieldwork was piloted in the Barumal village of Valsad district in Gujarat state, India under the supervision of our professors so as to get the first-hand knowledge of field techniques. The goal was to study the biological and socio-cultural facets of the Barumal village. The approach to study the people comprised understanding their kinship pattern, family, marriage, terminology, religion, political and economic institution. We poised a general ethnography of the village. I along with my fieldwork partner largely studied the folklore and traditions circling the myths of gods and goddesses amongst tribal populations.

Alan Dundes (1980) enunciates that the 'folk' are 'any group whatsoever that shares at least one common factor'. While interpreting the word folk he asserts that the discipline emerged in the nineteenth century with the first volume of Kinder und Hausmärchen which was celebrated in 1812 by the Grimm brothers, but the word folklore got coined in 1846 by Thoms (Dundes 1980). With the observations made during the study this essay attempts to unify the texts of cultural mixing of mythical tales amongst Dhodiya Patels, Kukanas, and Varlis without neglecting the most contemporary as suggested by Stuart Blackburn and A. 
K. Ramanujan (Srinivasan 1988). Looking at the colonial ethnography one finds the sparse evidence of folkloristic in India, but modern study involves intensive field with proper research in the linguistics as well thus making the contribution immense. The English speakers often associate Indian 'folk' with villagers and 'folklore' with confined and authentic materials which is definitely changing its shape in the post-colonial era if compared with the colonial literature (Narayan 1993). Reading the myths about the Gods and Goddesses suggests that the histories of three tribal groups overlap in one way or the other. Thus any anthropologist or folklorist would agree that traditions are always invented and reinvented (Hobsbawm and Ranger 2012). The folkloristics of all the three tribes about their Gods and Goddesses has been formally instituted as the journaled stories in the text below are an important part of their periodical festivities.

\section{Methodology}

There are various field methods or techniques through which scientific field data are collected. In this study following methods were employed - Interview method and Observation method. This interview method is considered to be the most important tool of research. Interviewing is an effective, informal, verbal conversation initiated for a specific purpose and focused on procuring information about certain planned contents. The interview may be structured or unstructured. In a structured interview, the interviewer prepares a set of questions in advance and is unambiguously dedicated to seeking the answers whereas in an unstructured interview no questions are set from first. It is more of spontaneous, it is time-consuming but the plus point is that it yields a lot of information apart from the particular topic in which the interviewer is interested. It could also be the amalgamation of

both.

Observation method is also correspondingly important for different types of research works. Broadly speaking observation method is of two types - Participant and Nonparticipant. In participant observation method, the researcher has to collect the field data by participating in the undertakings of the natives. In the case of marriage studies, or ceremonies, festivals, etc. participant method is very useful. However, when one doesn't participate in the ceremony or ritual activities but collects the data by observing from a distance, this is called non-participant. In this study creation of rapport played a central role in congregating data from key informants. Anthropological research is usually carried out in the 'other cultures' i.e., different social set up and the anthropologist's effort will not succeed if the researcher remains a stranger to the people. Thus, a fieldwork actually commences with rapport establishment which benefits in breaking down the feeling of hostility, shyness and unfamiliarity.

There are different kinds of stories prevalent according to the oral traditions, belief systems and the values of Varlis, Kukanas and Dhodia Patels.

\section{Stories about the origins of Varlis, Kukanas and Dhodia Patels}

(Varlis)As the old tales say, the Varlis once inhabited the region near Dharampur, which is 
the nearest town to Barumal village. The name Varlis was given by the great historian Megasthenes himself. The oral tradition of Varlis also lacks any mention of the sea about the arrival of Megasthenes. Since this hypothesis can't be proved so the origin is still a myth and could be covered by a different myth associated with cattle hide. The Varli king gambled with his own monarchy against Popera king from another kingdom who was supposed to cover the entire land with a cattle hide. Popera won, resulting in the Varlis losing their kingdom. This loss is still remembered by them and is symptomatic of the loss of their identity today.

Another story is prevalent about Varlis and it is as - There is a very popular tale which is told to all the Varlis as how they came into being. It is said that there was nothing else on earth except water. In a huge tumbler, there was a boy and girl. Both were Varlis. They gradually mated and this led to the entire community of people. They believe that the whole humankind rose from that couple. Also, some say that they are actually Kukanas. But due to some mishaps and distribution of work, they were subjected to discrimination. Finally, they became what they are now.

(Dhodia Patels) It is believed that a group of people called "Dodhka" who used to live in central India, grazed cattle there. They were initially pastoralists.

As the time passed, Dodhkas were forced to work under the Saurashtrians, who were the initial settlers of the time in the region of modern-day Maharashtra. If the Dodhkas refused to work under them, they were tortured; as a result, these people migrated and came to this part of Gujarat. These people were later known as Dodhiyas and the most well to do families among the Dodhiyas are called the 'Dodhiya Patels'.

The approximate population of Barumal village is around 3000-3500. This village is divided into small hamlets, locally known as 'Faliya' or 'Phaliya'. The origin of the names of these faliyas is variable, for example, Patel faliya is named so because the majority of the Dodhiya Patel are concentrated in this hamlet; another example is Dairy falia which gets its name from the presence of the women only managed dairy processing factory in the village.

\section{Myths behind festivities: Gods and Goddesses -}

The myriad of tales assorted about the Gods and Goddesses in the text below are the indirect reflection provided by the key informants, translated from Gujarati and Hindi descriptions.

Hirva is a clan God - worshipped once a year and is kept inside a basket called a salad. Bhagat who is the village priest chants in front of the image of Hirva placed within a square drawn using the white paint made from wet powdered rice. This occasion celebrates the birth of the child of God Hirva and Goddess Garija which marks the creation of another God (Dandekar 1998). There are inferences coming down from several generations about the birth of Hirva's son from different key informants, one of those inferences is written below and it has been refined after referring the book about Varlis by Dandekar - 
The wife of Hirva god asks him to cook some food for both of them as the wife Garija is on her period. He reminds her of him being the lord but later he somehow agrees and cooks it. After her menstruation cycle completes they had intercourse thus enabling Garija to become pregnant. That is how the story goes about the birth of God on this earth.

Kanashri devi - The word Kanashri is used by the farmer for paddy or kanis. The nagli (bajra) grain is considered to be important and Kanashri is related to it. At the time of sowing, the farmers give special respect to the grain and then follow some kind of fast and abstention from drinks and from certain vegetables like radish, plantains, cucumber etc. At the end of the harvest, a special ceremony is performed by the farmers by calling the Gangli bhagat (priest) and an assistant Zun bhagat. The word Gangli is a special mention for a musical instrument with two pumpkins joined with a bamboo road with two wires called dutari. The bhagat sings the Kanashri song 'khand' in praise of the devi (goddess) who is kind and has tremendous power. If the goddess is upset it is considered a big offence and may lead to a bad crop and even starvation. Hence, the farmers make it a point to placate the deity as it also brings wealth. The goddess Kanashri is personified as dark, short, ugly and lame. Also, she is known as Bengal ai, a lame mother. The reason of lameness is unknown.

Sometimes after the harvest farmer and his wife who have kept the fast invite their friends to the khala, a gathering. A heap of nagli grain is made in front of the med, which is a protruded platform made of mud used as a stove, a lamp is lit, the bhagat sits in front of the med with the household and Zun bhagat. The bhagat then makes rice punjali in front of the 'med' and chants his khands (his course of mantras) in praise of the Kanashri. The Zun bhagat who gets possessed by a spirit, he later becomes stiff and can't walk. His legs get crouched and begin to move only on his seat. Kanashri is thought to be the possessor; bhagat begins to complain speaking the words of Kanashri about the ill treatment by the farmer for burning her, abusing her not being generous with those in need of grains. Burning implies the roasting of the bread. The Varlis say that it was not, in their tradition, to bake the bread on both sides in early days as it meant that were burning the Kanashri. This is the reason why the zun bhagat states that he was burned and maltreated. Also, it is considered that the housewife resembles the Kanashri goddess; hence any ill treatment meted out on her by the husband is considered an offence to the Kanashri goddess. The Kanashri goddess through the zun bhagat, asks the main bhagat whether there has been a sacrifice performed of a black cock and a chicken and black goat and another goat for placation. If bhagat says yes, the Kanashri goddess leaves the zun bhagat and people stretch his hands and feet and make him stand. The sacrifices are made for the goddess and also for other gods. Then the chicken is roasted and kept hanging on the palad till the next day to be consumed in the morning by the family 


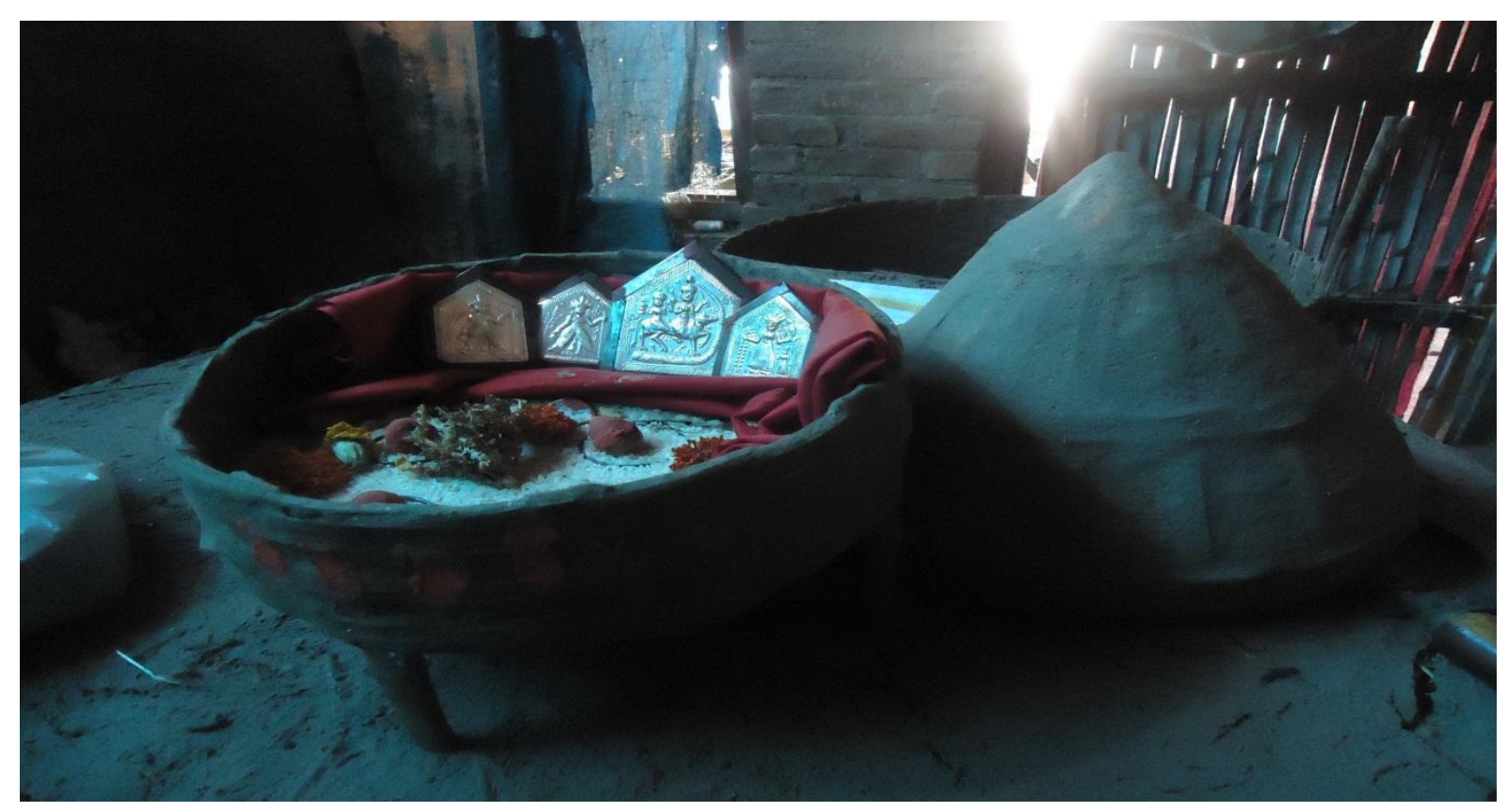

Fig 1. Kanashri holding Kul Dev with rice, sindur, and other significant objects of religious importance. Next to it, is the conical cap to cover the Kanashri

Dev (a Hindi term for God) - Every household keeps a Dev inside their homes in a separate room. The Dev is kept on a drum made of mud and cow dung in which they store their rice grains. When the drum fills completely they break it open and consume the grains. Another rice drum is made and dev is placed on top of it.

Dev is their god whom they worship every day although nowadays they even worship popular Hindu gods; dev still remains a part of their lives. Every 5 years dev is married and it is this time that Dev is kept outside of the house for others to see. The ceremony is performed by a Kukana bhagat (shaman). This practice also requires a person to own money in order to get their Dev married.

Dev or Kul Dev: In every household in Barumal village, there is a place designated for the ancestral God which seems to be the protector of that particular family. It is placed inside of a clay tub with some sindur, rice, a photo of a god and red threads. This is then covered with a conical cap made of mud and cow dung. The cap is marked with sindur.

Kadica Dev - A prayer is done for the eradication of pests. It is done indoors with dhum (incense) coconut and water.

Dhingla and Dhingli - Divasa a festival in which idols Dhingla and Dhingli are made by unmarried girls of the house only. There is a kind of story prevalent amongst Dhodias that for bringing prosperity and happiness on the last day of Ashadha (fourth month of Hindu calendar year). These idols are worshipped for two days. During those two days, almost a marriage ceremony is performed considering Dhingla as groom and Dhingli as a bride. The other reason is the removal of Chickenpox such rituals are finished, the idols of the couple are immersed in the river water marks the end. The idols are taken to the bank with a whole 
music band and celebrating crowd.

Sheetala shatam is a festival which is celebrated during the first six days of the Shravan (fifth month of Hindu calendar year) and the seventh day is the most important, where final patience of the family is checked by the God if it could resist to not have the food cooked in the kitchen. Basically, it comprises a rule where stove in the kitchen cannot be burnt, for continuous seven days and if someone burns the stove in his/her house Sheetala Mata is displeased, she becomes angry and punishes them by burning their bodies. In the similar lines, there is a story prevalent about two daughters-in-law, in general, the senior daughterin-law is called as Jethaani wife of elder brother and junior one as Devraani, wife of a younger brother. Devraani was a great follower of Sheetala Mata and she was worshipping her for throughout the seven days but, her Jethaani was an atheist and always used to envy her Devraani and her devotions for Sheetala Mata. Devraani had managed a great pain for continuous seven days to worship her without cooking anything in the kitchen of her house. For all six days everything almost went really smooth but in the end, on the final seventh day Jethaani couldn't resist cooking and she burnt the stove and started cooking. So Sheetala Mata appeared there who was vehemently angry with her deed. Sheetala Mata punished Jethaani by burning her son's body. Since then it is strictly followed that people don't cook during that period of seven days inside the house. This story is prevalent amongst Kukanas.

\section{Conclusion}

It is vital to bring the myths and legends of the tribals in order to discuss the religious life. Myths help us know from the perspective of tribals about the world. For the Hindu religious dwellers there are a few scriptures of great significance and in the same way, these myths and legends fill in for the tribals. According to the gathered data, what has been understood about these three tribes is that these religious minds give sanction to their festivities, birth rituals, marriage traditions, and daily activities as well. About the universe, there are several myths prevalent amongst tribal India. Varlis, Kukanas, and Dhodiya Patels too consider the role of the supreme power in the creation of this earth and of the mankind. Every myth seems explicable which they speak of to be an action of the superhuman. Like in the mythos prevalent amongst Varlis, they consider some historical figure or a king as their clan god. All the occasions and events have a sacredness attached to them that can only be explained with a myth. The tribal India has an abundance of myths and legends for every activity they perform.

\section{Acknowledgement}

The field trip wouldn't have been completed without the valuable support Department of Anthropology, University of Delhi, Delhi. I am very grateful to Prof G. K. Kshatriya for the proper guidance throughout the field trip. He was always there to help us, clearing our doubts whenever we put forward. Overall the field trip has been very educational.

\section{References}


Dandekar, Ajay 1998. Mythos and logos of the Warlis: A tribal worldview, Concept Publishing Company, https://perma.cc/TQ4Q-LMNT (last accessed on 26 April 2017)

Dundes, Alan 1980. Interpreting folklore, Indiana University Press, https://perma.cc/8N3U-

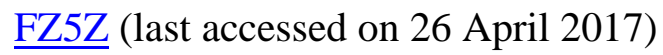

Hobsbawm, Eric and Ranger, Terence 2012. The invention of tradition, Cambridge University Press, https://perma.cc/TQ7P-J64F (last accessed on 26 April 2017)

Narayan, K. 1993. Banana republics and V. I. degrees: Rethinking Indian folklore in a postcolonial world. Asian Folklore Studies 52(1), 177-204, https://perma.cc/WX9P-G9QV (last accessed on 26 April 2017)

Srinivasan, A. 1988. Review of another harmony; New essays on the folklore of India. Sociological Bulletin 37(1/2), 147-151, https://perma.cc/K6W9-L2BP (last accessed on 26 April 2017) 